\title{
The llama and the deer: dietary and symbolic dualism in the central Andes
}

\section{Nicolas GOEPFERT}

CNRS

UMR 8096 "Archéologie des Amériques » Maison René Ginouvès de l'Archéologie et de l'Ethnologie 21 allée de l'Université 92190 Nanterre (France) UMR 7209 « Archéozoologie, Archéobotanique : sociétés, pratiques et environnements "

Muséum national d'Histoire naturelle 55 rue Buffon, CP 56, 75005 Paris (France) nicolasgoepfert@yahoo.fr

\section{KEY WORDS}

Sacrifice,

funerary rites,

offering,

feast,

dualism,

Mochica culture,

Goepfert N. 2010. - The llama and the deer: dietary and symbolic dualism in the central Andes. Anthropozoologica 45(1): 25-45.

\begin{abstract}
The domestication of camelids, llamas and alpacas, took place between 6000 and $5500 \mathrm{BP}$ in the central Andes. These animals played a fundamental role in the development of pre-Hispanic societies. Among the Mochica (100-800 AD), a coastal culture of northern Peru, the meat consumed mainly consisted of camelids and guinea pigs but also deer, fish and shellfish. However, these wild creatures were not used in funerary rites, especially those involving the symbolic food of the dead. The latest ethnohistorical and ethnographic data confirm the continuity of these ritual practices. The llama has remained, up to our day, the only animal which may be consumed at special events, such as funerary meals or propitiatory ceremonies. This occurs in particular at Carnival, when the heart and the lungs of a sacrificed llama are offered, burned and symbolically consumed by the Apu (spirits of the mountain), the Pachamama (the Earth Mother) and the Tio (tutelary divinity of the mine). We will attempt to understand how the absence of wild animals in these rites corresponds to ancient cultural traditions, reuniting and opposing the terrestrial world and that of the divinities, the domestic world and the wild, this conceptual whole being a guarantee of order and continuity for the society.
\end{abstract}

\section{RÉSUMÉ}

Le lama et le cerf: dualisme alimentaire et symbolique dans les Andes centrales La domestication des camélidés, lamas et alpagas, s'est réalisée entre 6000 et 5500 B.P. dans les Andes centrales. Ces animaux ont joué un rôle fondamental 


\author{
MOTS CLÉS \\ Sacrifice, \\ rites funéraires, \\ offrande, \\ festin, \\ dualisme, \\ culture Mochica, \\ Pérou.
}

dans le développement des sociétés préhispaniques. Chez les Mochica (100800 apr. J.-C.), culture côtière du nord du Pérou, l'alimentation carnée était principalement composée de camélidés et de cochons d'Inde mais aussi de cervidés, de poissons et de malacofaune. Cependant, ces composantes sauvages ne sont pas utilisées dans les rites funéraires, notamment ceux portant sur l'alimentation symbolique du mort. Les témoignages ethnohistoriques et ethnographiques plus récents confirment la continuité de ces pratiques rituelles. Le lama est resté, jusqu'à nos jours, l'unique animal susceptible d'être consommé lors d'évènements extraordinaires, comme peuvent l'être les repas funéraires ou les cérémonies propitiatoires. C'est notamment le cas pendant le Carnaval, où le cour et les poumons du lama sacrifié sont offerts, brûlés et symboliquement consommés par les $A p u$ (les esprits de la montagne), la Pachamama (la Terre-Mère) et le Tio (divinité tutélaire de la mine). Nous tenterons de comprendre en quoi l'absence des animaux sauvages de ces rites correspond à des traditions culturelles anciennes, réunissant et opposant le monde terrestre et celui des divinités, le monde domestique et sauvage, cet ensemble conceptuelle garantissant l'ordre et la continuité de la société.

\section{INTRODUCTION}

In an article devoted to Andean agro-pastoral rites, Jorge Flores Ochoa (1974-76: 256) indicates that the herders of llamas divide the animal world into two categories: domestic animals $(u y w a)^{1}$ and wild animals (salqa). The first belong to humans while the second are the property of the Apus, the tutelary spirits of the mountains. We learn for example that "The fox is the wild equivalent of the dog and helps the Apu in protecting the herds and driving the llamas" 2 and that vicunas provide wool for the $A p u$, as alpacas do for humans. Structuring the environment in two parts is one of the many indications of dualism, a concept that has governed Andean societies since ancient times. These animals are the representatives of two opposing worlds - wild and domestic - which are however complementary and inseparable from one another. For these spirits, the fox and the vicuna play a similar role to that of the dog and the alpaca for humans: to protect and drive the herds and provide wool, respectively. J. Flores Ochoa (ibid.) emphasizes that the Andean deer, the huemul, locally called taruka, is considered to be the wild equivalent of the llama. Indeed, "The tarukas (huemul) are like llamas because they transport loads, especially on the night of the (full?) moon in August when they carry on their backs burdens containing gold and silver. The guanaco is a hybrid animal like the wari (Ilama crossed with an alpaca)". This description is quite surprising because we could have imagined that the guanaco would have been perceived as the wild ancestor of the llama, a link which has in fact been confirmed by DNA tests (Stanley et al. 1994). However it is the deer that fills, in the divine sphere, the same functions as the llama, especially the transportation of loads.

This paradox is the point of departure for this article. We will attempt to examine the symbolic relations that exist between the llama and the deer,

1. These terms are from Quechua, a pre-Hispanic language which is still spoken (like Aymara) in the Andean region.

2. The translation from Spanish to French is ours: "El zorro es el equivalente del perro y ayuda al Apu en el cuidado de los rebaños y la conducción de las recuas de llamas." All the article has been translated into English by E. Willcox.

3. The translation from Spanish to French is ours: "Las tarukas son como las llamas porque transportan las cargas, especialemente en la noche de luna del mes de agosto cuando llevan en sus lomos cosyales conteniendo oro y plata. Los guanacos se tienen por animales hibrido como los waris." 
but also between the domestic and the wild world; we will also try to understand why the camelids are the only animals consumed both in ordinary contexts - the domestic - and extra-ordinary contexts - tombs, funerary meals, propitiatory rituals... To answer these questions, we shall rely on three types of sources: the archaeological data from different pre-Hispanic cultures of Peru, especially that of the Mochica, the ethnohistorical documents established by the Spanish chroniclers and the ethnographic information gathered from presentday Andean populations.

\section{ORDINARY CONSUMPTION}

Camelids and deer were the main quadrupeds consumed by the humans living in the Andes in the pre-Hispanic period. Although there are several species of deer in the studied area, the most common are the Virginia deer (Odocoileus virginianus) and the huemul or Andean deer (Hippocamelus antisensis). The South American camelids consist of four species: two domestic, the llama (Lama glama) and the alpaca (Vicugna pacos), and two wild, the guanaco (Lama guanicoe) and the vicuna (Vicugna vicugna).

In Peru, the excavations of the rock shelter at Telarmachay (Lavallée et al. 1985) have shown that the alpaca and the llama were domesticated respectively between 6000 and $5500 \mathrm{BP}$ (Wheeler 1985: 60) and between 5500 and $5000 \mathrm{BP}$ (ibid. : 66). In parallel to the domestication process of the camelids, the consumption of deer decreased considerably, from $34.1 \%$ of the faunal assemblages (N.R.) between 9000-7200 BP to only $13.1 \%$ between $5500-5000 \mathrm{BP}$ and $9.2 \%$ between 5000/4500-3800 BP; for the same periods, the proportion of camelids continues to increase, from $64.7 \%$ to $88.6 \%$ (Wheeler 1985: 53-55, 57). Domestication was completely mastered by the Formative period (1800-200 BC). They then became the main animals consumed and the primary source of animal protein for the Andean populations, whether coast-dwellers or mountaindwellers, such as the Mochica (Pozorski 1976; Shimada \& Shimada 1985; Vasquez et al. 2003), the Nasca (Valdez 1988) and the Wari (Pozzi-Escot \& Cardorza 1986).

Although they represent only a tiny part of the meat consumed by the population, deer were always hunted and are found in small quantities in domestic rubbish dumps. Thus it is necessary to investigate the nature of deer hunting and attempt to learn whether it took place to obtain meat or whether it was practised only for ritual purposes, as C. Donnan (1982a) suggests for the Mochica period.

\section{WHY FEED THE DEAD?}

In the Andes, as in other parts of the world, death is not perceived as an end, but rather as a rebirth in another sphere. At death the deceased passes from the world of the living to that of the ancestors who are supposed to reside in the netherworld. The Andean cultures in particular include ancient traditions that have persisted and are still observable in situ, especially those that concern death.

The pre-Hispanic cultures of the Andean region all possess their own specificity and their own conception of death and the sacred (Benson 1975; Bourget 2006; Donnan \& McClelland 1979; Kaulicke 2000; Millones \& Kapsoli 2001).

Still today, the Quechua and Aymara populations of the Peruvian and Bolivian high plateaus continue to maintain special relations with the dead, which ensure the cohesion of the group. The dead intervene in the way of life of these peoples, in areas as diverse as the social order, the definition of space, and fertility (Bouysse-Cassagne \& Harris 1987: 37-41). This conception of the world enables the view that the souls of the dead travel to the world of the ancestors whose location varies according to region and belief, but which could be a volcano or a lake in the sierra (Bouysse-Cassagne 1988; Robin Azevedo 2004, 2008), or a guano island ${ }^{4}$ for the coastal populations (Arriaga 1920 [1621]: 70).

4. The term guano island designates a series of islands located a few kilometres from the littoral and running along the Pacific coast of Peru. They were exploited by the local populations beginning in the pre-Hispanic period to extract the guano (faeces of marine birds) that had accumulated and which constitutes an excellent fertilizer. 
The rites of expulsion of the soul of the deceased towards the netherworld are thus very important, in that the soul must be sent on in order not to disturb the political and religious organisation of the community and not provoke catastrophes (Harris 1983: 145-147); this is why many animal sacrifices are practised and food offerings are made. The nourished soul is expelled and must reach the netherworld to join those of the other ancestors who have become partly divine.

\section{EXTRA-ORDINARY CONSUMPTION: TOMBS AND DEPOSITS OF OFFERINGS}

\section{TOMBS}

Graves are exceptional contexts which must be differentiated from domestic sectors, places of ordinary consumption. The presence of faunal remains in these assemblages can be interpreted, in certain cases, as the vestiges of extra-ordinary consumption. To be considered as such, these offerings must, in our opinion, fill the following criteria:

- the context: it must be a grave (or a deposit of offerings) as tombs played a particular role, and even when located within dwellings, they formed a specific ritual space which was symbolically situated outside the domestic sphere;

- the time framework: the time of the ritual was different from that of daily life, which is why the funeral rites were probably imbued with an extraordinary character and their own temporality; - the individual addressed: extra-ordinary consumption concerned the deceased and not the living. It occurred in the world of the dead, a place of inversion of the natural order of things;

- the anatomical nature of the animal offering: the bone remains must correspond to a fleshy part of the animal, (shoulder, haunch, ribcage, etc.) to be considered as a meat offering.

\section{The camelids}

The domestication of the camelids is a process that profoundly transformed Andean societies. The llama and the alpaca can be considered to be the most important animals of the Andes (Browman 1974; Lecoq 1987; Lavallée 1990: 31; Flores
Ochoa et al. 1994). Indeed, they are the main source of raw materials - meat, wool, leather...-, they participate in the social and economic life of the communities - work animals - and they are used in rituals - offerings, foetuses, intestinal calculi... In Peru, the first animal sacrifices were observed beginning in the Preceramic (which ended in $1800 \mathrm{BC})$, as at Kotosh (2500-1800 BC for the Mito phase) where the bone remains of camelids were discovered in a niche of the "Temple of the Crossed Hands" (Izumi \& Sono 1963: 46, 153). Beginning in the Formative (1800-200 BC), we find them more frequently in the funerary and ceremonial contexts of the different pre-Hispanic cultures (Goepfert 2002). Thus, the camelids became - and remain - the main victims of animal sacrifice in Peru and in the entire Andean region. They were deposited in several types of context - funerary and ceremonial - and in various forms (complete bodies and specific parts). In order to describe these complex ritual practices, we use data that we have obtained during the analysis of faunal remains from Mochica burials and deposits of offerings (Goepfert 2008, 2009).

The Mochica culture developed between 100 and $800 \mathrm{AD}$ on the northern coast of Peru, between the Piura and Huarmey valleys (Fig. 1). This preHispanic culture is known for its impressive step pyramids, constructed in adobe, which were decorated with polychrome wall paintings, but also for its vessels, metal ornaments and other objects found in the tombs (Donnan 1995; Castillo Butters 2000; Chauchat 2000; Millaire 2002).

Among these many material remains, the Mochica also deposited animals (mammals, birds, reptiles), mainly camelids. The anatomical elements most frequently buried were the skull and the extremities of the limb, but we have also identified other, more meaty parts, such as ribcages and vertebrae (Goepfert 2009). As on certain Roman and Iron Age deposits in Europe (Méniel 1992: 91-110, 2001: 88-89; Lepetz \& Van Andringa 2008a: 16, 20-23), we have suggested that these specific parts were intended symbolically to feed the deceased during the journey to the netherworld.

The location and the disposition of the camelid food offerings varied in the Mochica burials. An entire animal could be cut up and buried as quarters or 


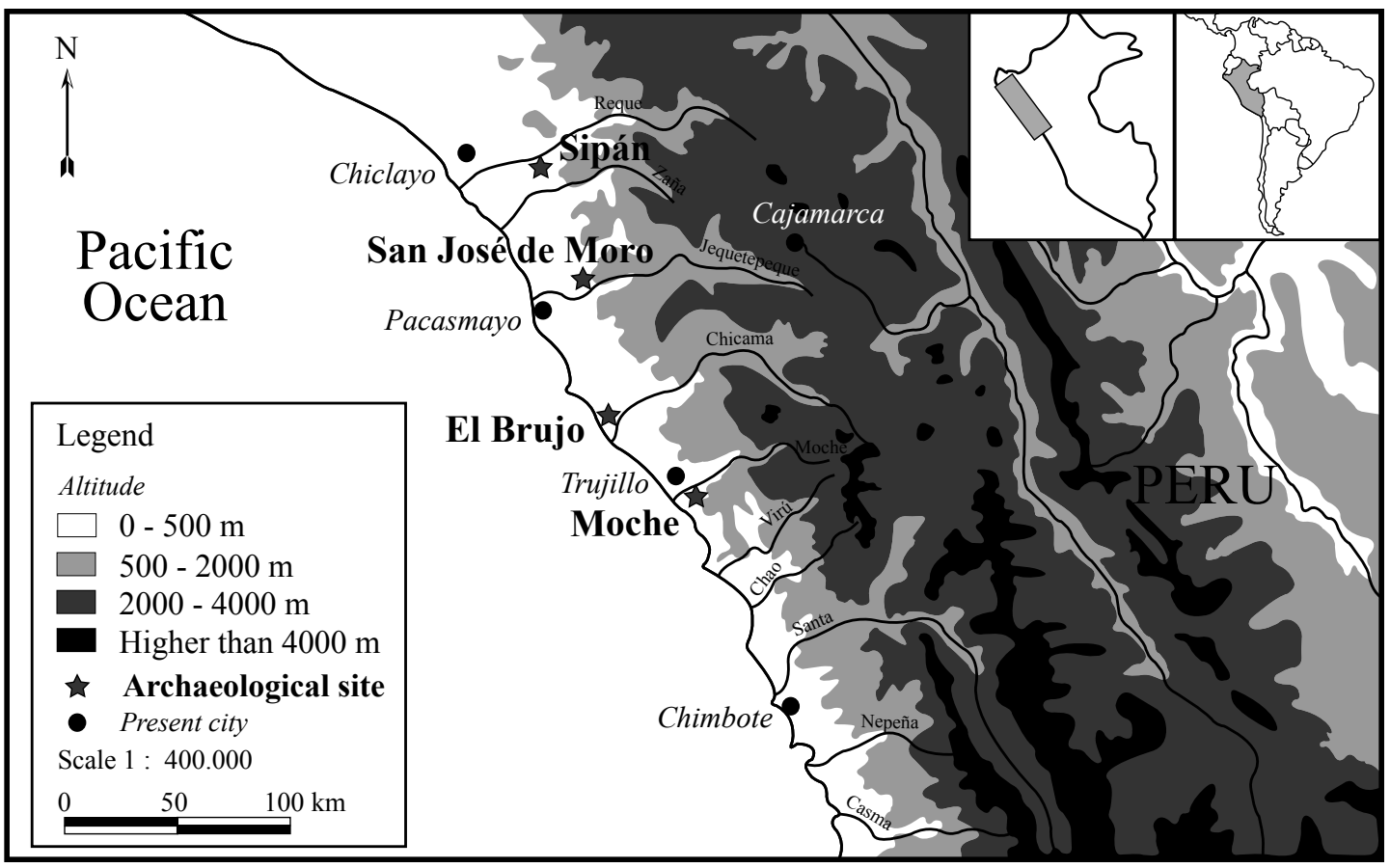

FIG. 1. - Map of location of the principal Mochica sites on the northern coast of Peru. Map N. Goepfert.

"pieces of meat" as in tomb 48 (Fig. 2) of the Uhle Platform situated on the site of Moche (Chauchat $e t$ al. 2008: 120-121). This is a funerary chamber constructed in adobe containing the body of a male individual, buried with many funerary objects. The faunal assemblages were deposited within this chamber, beside and between the vessels. All the tombs do not contain so many offerings, which probably vary according to the social status of the individual. In other funerary contexts, the specific anatomical parts that are buried are ribcages (Fig. 3; Goepfert 2009: 242-245, 375), thoracic vertebrae (Goepfert 2009: $241,375)$ and complete limbs, as seen in the deposit of a right front foot of a camelid (Fig. 4) in tomb 40 of the Uhle Platform (Goepfert 2009: 246).

However, these elements were not deposited on the floor of the the tomb itself. According to the representations available in Mochica iconography, the meat and plant offerings were placed in recipients of pottery or of plant material. These are, in most cases, superimposed dishes, like those visible in the scene called "Presentation of Offerings" (Larco
Hoyle 1939: plate XXXL). This figure (Fig. 5) shows individuals of the elite, recognizable by the finery, headdresses, ear and pectoral ornaments and bracelets worn by these persons, to whom individuals of inferior social rank - painted as smaller and with no ornaments - present many dishes and jars (Fig. 5). It is clear in this scene that the recipients were superimposed, the whole giving an impression of a profusion of dishes and reflecting the presumed wealth of these persons.

Similarly, "the circular shape" of certain deposits (Fig. 6) suggests that these pieces of choice were first placed in recipients, especially gourds (Lagemaria sicezaria). In rare cases, the preservation of the remains is good enough that the plant material is preserved (Fig. 3).

Tomb 46 of the Uhle Platform provides excellent examples of this preservation. The offerings were laid within and outside a reed coffin which contained the remains of a male individual (Chauchat $\&$ Gutiérrez 2007: 72-75, 2008: 45-47). Next to the skull and the four extremities of camelid limb, two 
Goepfert N.

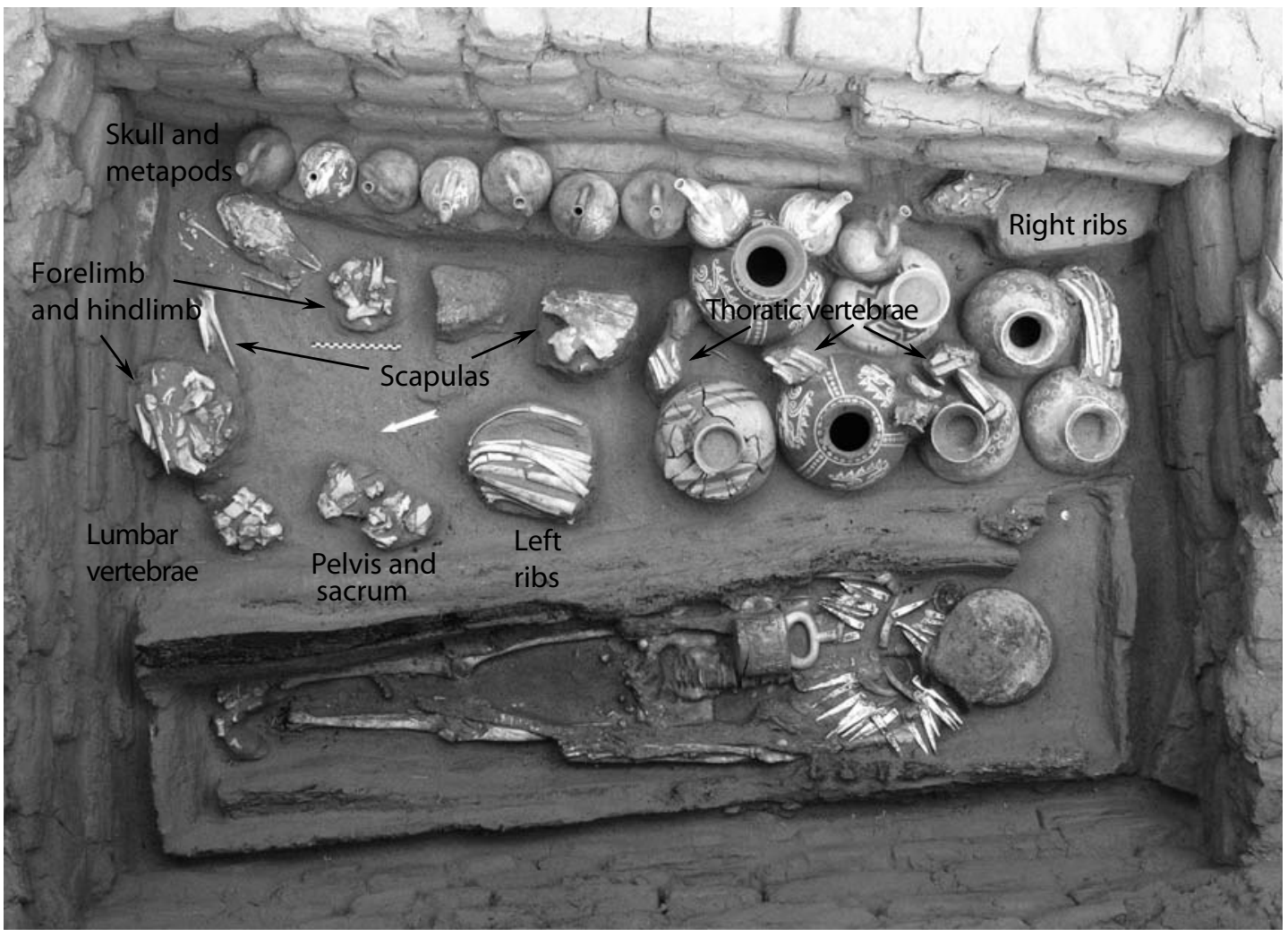

FIG. 2. - Tomb 48 of the Uhle Platform at Moche (Photo C. Chauchat - International Program Moche).

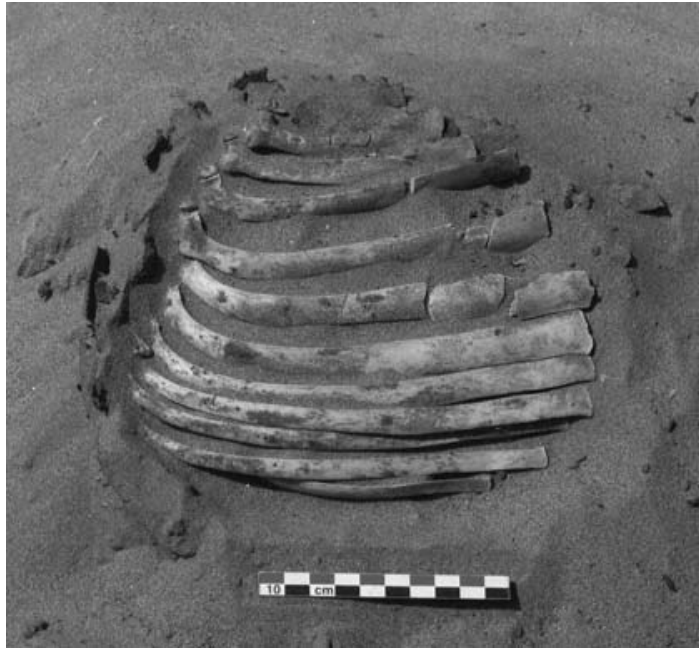

FIG. 3. - Right-side ribcage of a camelid from Tomb 46 of the Uhle Platform at Moche (Photo C. Chauchat - International Program Moche).

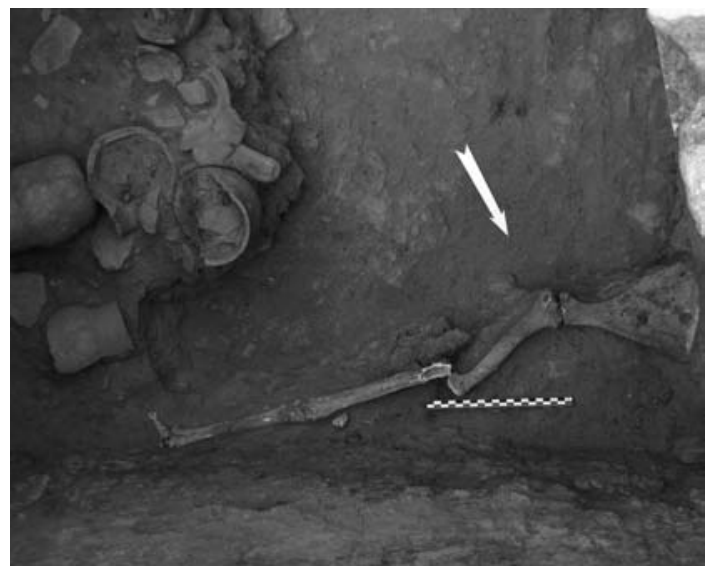

FIG. 4. - Front right hoof of a camelid deposited in Tomb 40 of the Uhle Platform at Moche (Photo C. Chauchat - International Program Moche). 
Superimposed dishes

Jars solid foods

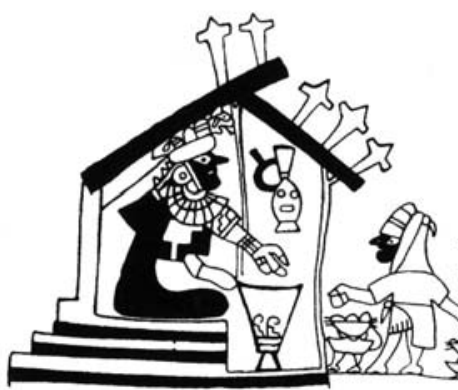

(animal or vegetable)

liquids

(chicha?)

FIG. 5. - Scene called the "Presentation of the Offerings" (Modified after Larco 1939: plate XXXL.
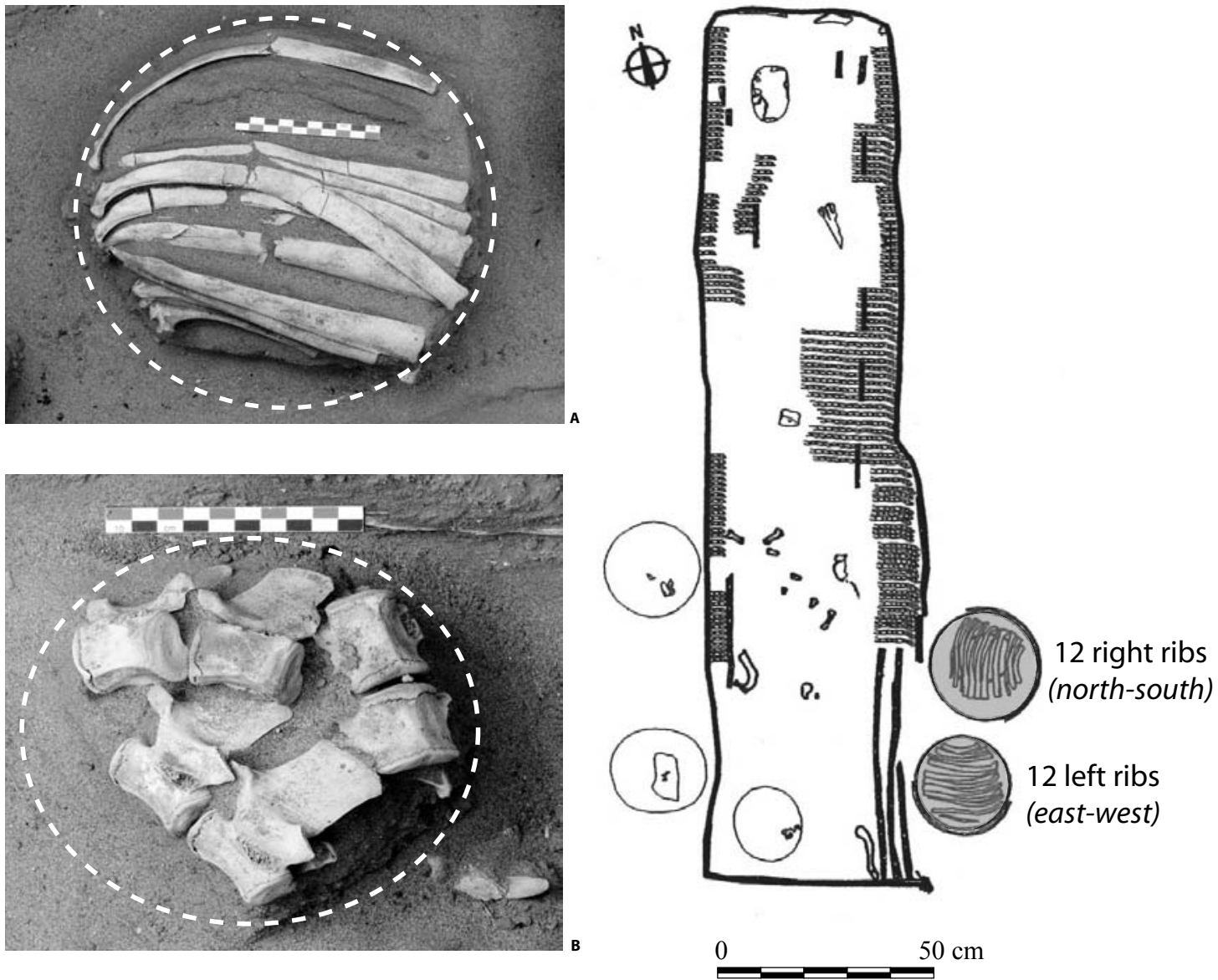

FIG. 6. - Detail of the camelid offerings of Tomb 48 of the Uhle Platform at Moche in which the impression left by a gourd may be observed (Photo C. Chauchat - International Program Moche). ). A. Left ribcage; B. Lombar vertebrae.

FIG. 7. - Plan of tomb 40 of the Uhle Platform at Moche (Modified after Chauchat C. \& Gutiérrez B. 2008: 46, fig. 67). 


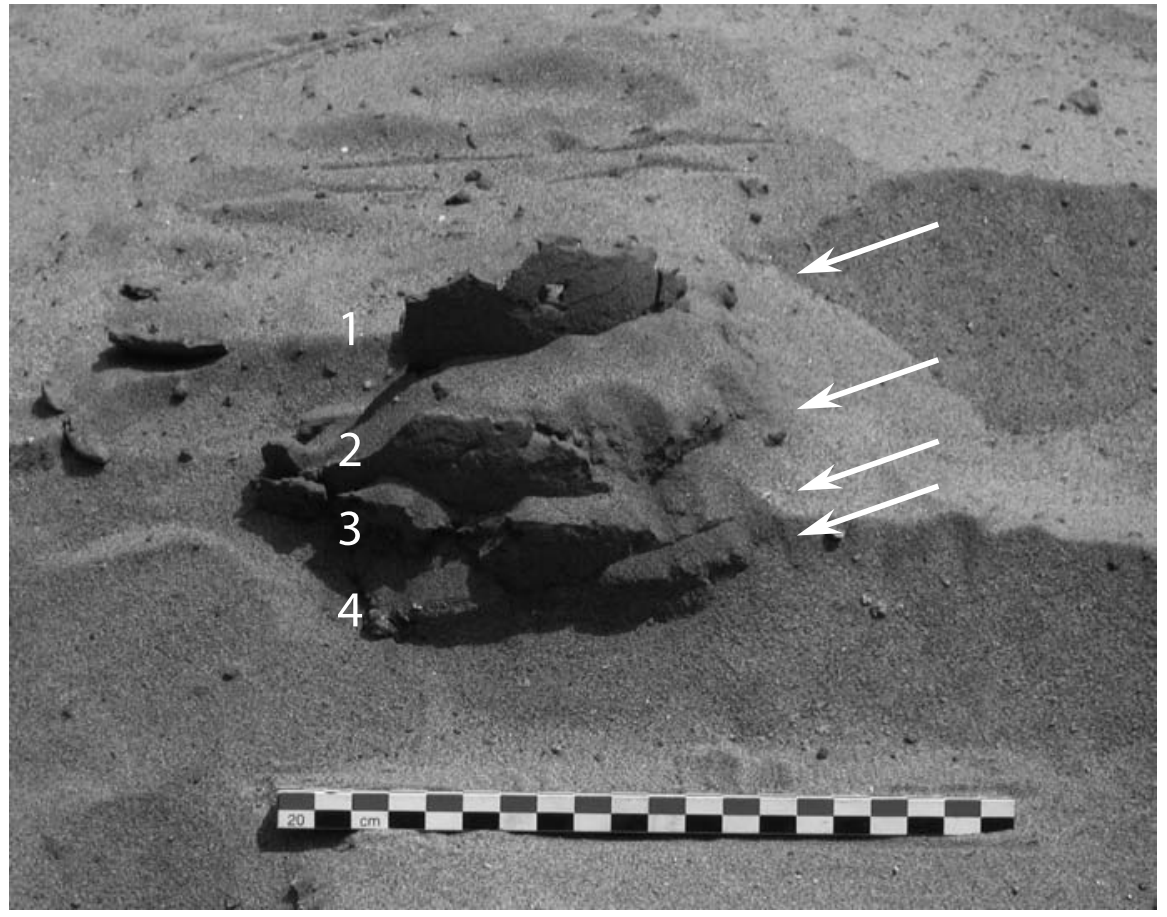

A

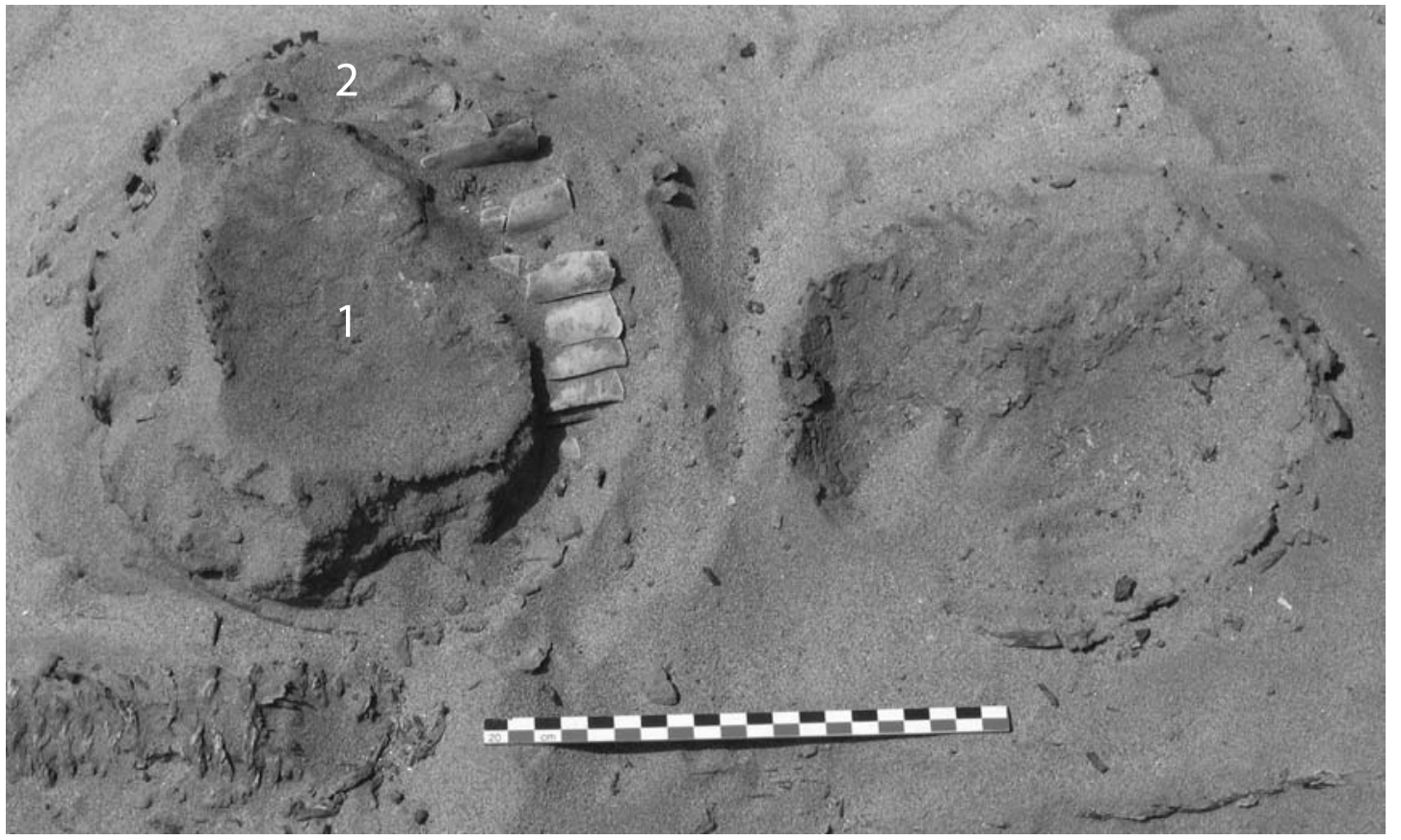

FIG. 8. - Detail of the arrangement of the ribcage in Tomb 40 of the Uhle Platform at Moche (Photo C. Chauchat International Program Moche). A. Four superimposed gourds; B. Right ribcage visible under the remains of a gourd. 
ribcages (right and left) were placed in two gourds located in the south-east corner of the grave, to the east of the coffin (Fig. 7). Their arrangement is in fact much more complex, as this is a group consisting of four superimposed gourds (Fig. 8A) of which only the second contains the above-mentioned ribcages (Fig. 8B).

We find here, in situ, and thanks to adequate field recording, the presence of superimposed dishes containing offerings of meat, like those represented in the previously described scene (Fig. 5) and abundantly represented in Mochica iconography (Fig. 9; Benson 1972: 80, figs 4-8; Berrin 1997: 124, fig. 60; Donnan \& McClelland 1979: 33, figs 21-22; Kutscher 1983: fig. 161). Thus, thanks to the archaeological discoveries, we may observe that these vessels (Fig. 9) faithfully reproduce the superimposition of gourds observed in Tomb 46 of the Uhle Platform (Figs 7 and 8). However, the tombs do not all contain such deposits and it is possible, according to D. Arsenault (1992: 58-59), that the Mochica had introduced these vessels as symbolic substitutions of offerings and gifts in kind, to fill the absence of food in the tomb.

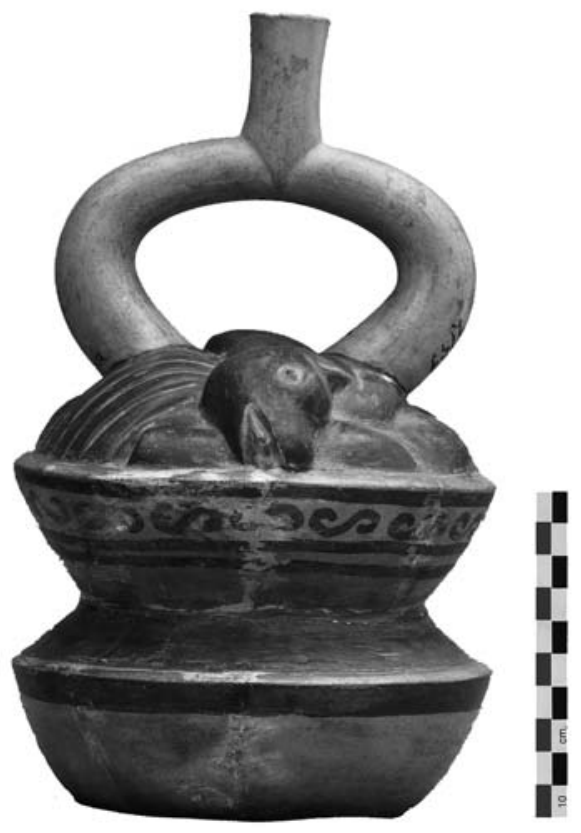

The deposit of fleshy parts of camelids was probably the main food offering of the Mochica, in many cases accompanied by other elements, especially plants, such as maize, avocados and other species of vegetables and fruit, also found in the tombs (Gumerman 1994, 1997). However, these remains are rare in the burials, as their preservation is unlikely.

\section{The deer}

Unlike the camelids, the deer found in the Mochica tombs are limited to a few examples. Only three tombs (Goepfert 2009: 256, 326-327) have produced deer remains, a mandible and two antlers. As these tombs have been subjected to various disturbances, it is possible that these elements are intrusive, and thus there is possibly a total absence of deer in the Mochica tombs. Moreover, these elements are not fleshy parts (no meat at all in the case of the antlers) and thus would not have been food offerings for the deceased, this function being reserved for camelid meat.

Deer remains are found in Mochica domestic contexts (Pozorski 1976; Vasquez et al. 2003) in

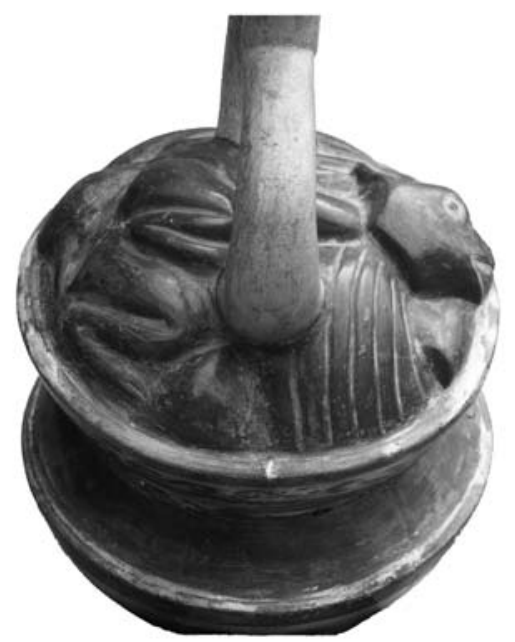

FIG. 9. - Stirrup spout bottle embossed with decoration representing superimposed dishes containing parts of a llama. (Inventory number: C-03414, Museo National de Arqueología, Antropología e Historia del Perú, Lima, Peru.) 
tiny quantities, but these vestiges are nevertheless evidence that the animals were still hunted.

The iconography provides more information on the place occupied by deer in Mochica society. Indeed, there is a series of representations of which the most famous are entitled by specialists as "the deer hunt" (Donnan 1982a; Hocquenghem 1983). Again, these illustrate personages of the elite, wearing many ornaments, armed with spear throwers, javelins and maces, accompanied by assistants and dogs to drive the deer towards large stretched nets in order to capture them (Fig. 10). Given the rareness of remains of this animal in Mochica domestic deposits, C. Donnan (1982a: 246) has proposed the hypothesis that this hunt was essentially ritual. He compares it to the Inca chaku, the hunting of the vicuna organised for the Inca emperor (Donnan 1982a: 241, 244).

However, the presence of deer in the iconography is not limited to these scenes. Unlike the camelids (llamas and alpacas) which are always depicted realistically, deer can be painted in different ways: realistically (Berrin 1997: 98, fig. 29; Donnan 1978: 58, fig. 85), "dancing" (Hocquenghem 1987: 140, fig. 146a) or with anthropomorphic features (Berrin 1997: 160-161, fig. 104-105; Donnan 1978: 134, fig. 210).

Although we have also found iconographic representations of camelids in the world of the dead (Donnan 1982b; Goepfert 2009: 458-459), it appears that deer are more frequently associated with this realm. A.-M. Hocquenghem (1983: 75-79, 1987: 140) links deer to death by placing in parallel representations of the "dance of the deer" with those of the "dance of the dead". According to her (ibid. 1983: 77), these scenes refer to rituals whose objective is "the distancing of the dead". This relation probably follows on from the place occupied by deer in pre-Hispanic societies: a figure linked to totemic aspects from the social point of view and to shamanic rites from the ritual point of view.

\section{THE DEPOSITS OF OFFERINGS}

Besides the tombs, other exceptional ceremonial contexts have produced faunal remains. Deposits of offerings are varied, complex assemblages whose composition is close to that of the tombs, although without human remains. They are the manifestation of complex rituals, still difficult to understand but for which the archaeozoological analysis has produced, in certain particular cases, new information which has enabled a new interpretation.

Among the many deposits recorded (Donnan 2008: 130-148, 163-165, 182-185; Goepfert 2009: 330360 ), we will concern ourselves with one example, the deposit of Offerings I discovered at Sipán, presenting a synthesis of results for which the detailed analysis was carried out during our doctoral research (Goepfert 2009: 166-183).

\section{The deposit of Offerings I at Sipan: description of} the archaeological results

Sipán is a ceremonial centre on the northern coast of Peru (Fig. 1) well-known as the place where the tomb of the "Lord of Sipán" was discovered, considered to be the richest burial in South America
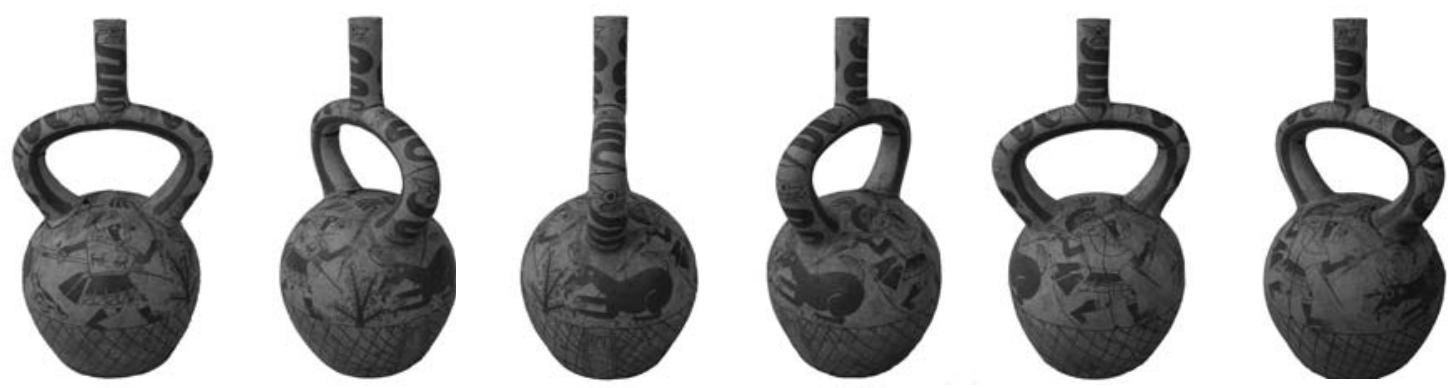

FIG. 10. - Stirrup spout bottle having painted decoration representing the "Deer Hunt". Tomb 22 of Uhle Platform at Moche (Photo C. Chauchat - International Program Moche). 
(Alva \& Donnan 1993; Alva 2004). After the burial of this Mochica high dignitary, a large deposit of offerings - $2.90 \mathrm{~m}$ long, $1.80 \mathrm{~m}$ wide and up to $1.10 \mathrm{~m}$ deep - was built and its excavation produced thousands of material remains distributed in several layers. It contained 1137 pottery vessels, four copper crowns, a copper mask, several small copper objects, spondyles, lithic objects, and remains of vertebrae (Alva \& Donnan 1993: 50-53; Alva 2004: 32-37).

From a taxonomic point of view, the bones correspond exclusively to camelids. However, it is impossible to determine whether there were other taxa. The lack of sieving during the excavation could have influenced the quantity and size of the materials recovered, with loss of smaller species due to this inadequate sampling. We believe however that camelids were the only animals deposited in this type of structure, probably accompanied by liquid products, such as chicha (alcoholic drink of preHispanic origin made from maize) and other perishable foodstuffs (vegetables and fruit).

The bone remains from the Offerings I deposit are highly fragmented and in a poor state of preservation. The number of camelid remains analysed (N.R.) is 4436 of which 1673 have been determined, $37.8 \%$ of the total. The high percentage of undetermined remains, $62.2 \%$, is due to the high fragmentation of the bones. Their size is variable: most of these remains measure less than $1 \mathrm{~cm}$ and correspond to fragments of diaphysis; others measure between 1 and $3 \mathrm{~cm}$, being fragments of undetermined epiphyses.

The Minimum Number of Skeletal Parts (M.N.S.P.) provides evidence for at least 17 camelids in this deposit of offerings (Tab. 1). The two anatomical parts most frequently found are right cuneiform bones and left astragali, each numbering 17 .

Figure 11 illustrates more clearly the inequality in the frequency of anatomical parts recorded in this deposit. In spite of the imbalance between the different elements, between the right and left sides, the whole of the skeleton is represented. The forelimbs and hind limbs are the most numerous, especially the humerus, the radius-ulna, the femur and the tibia. These elements correspond to the parts of the camelid body richest in meat (Mengoni Goñalons 2001; Olivera 2001). The
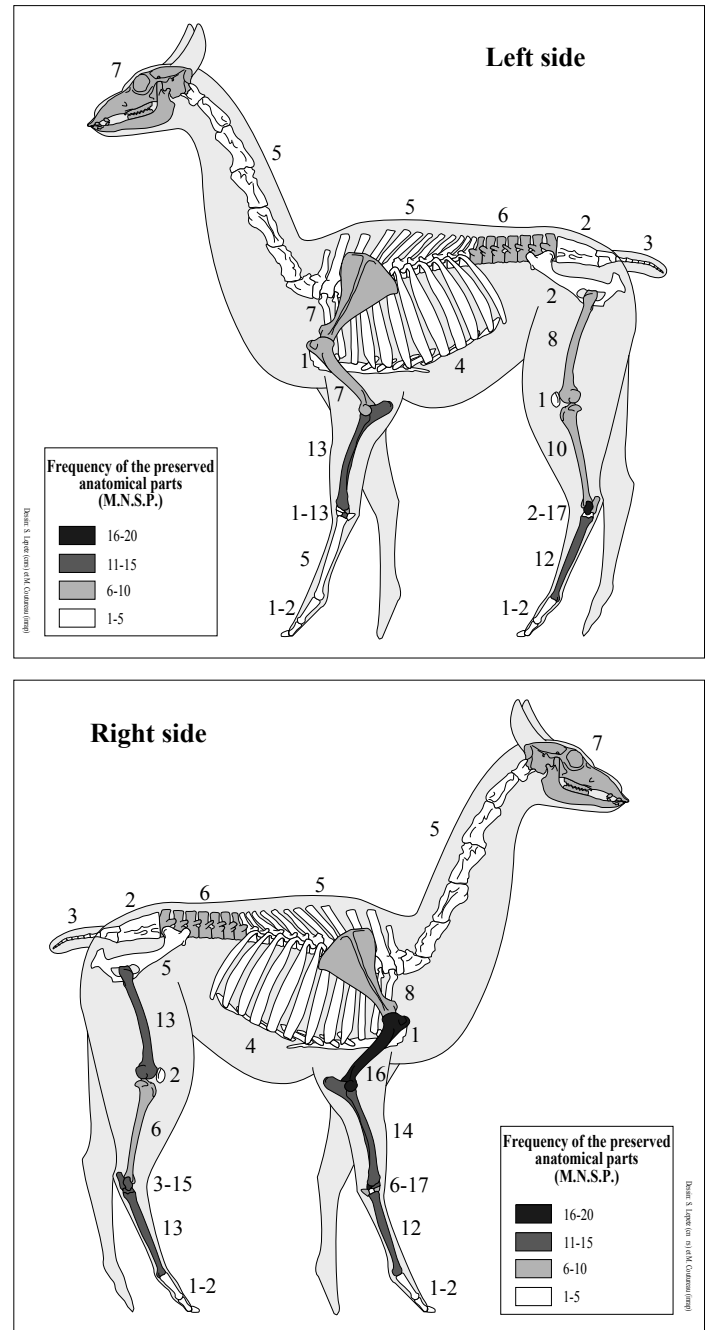

FIG. 11. - Frequency of anatomical parts of camelids from the Offerings I deposit at Sipán.

proportion of carpi, tarsi and metapodia is higher than that of the vertebrae and the ribs for two reasons: on the one hand, their identification is easier and on the other hand, their resistance to fragmentation is higher because of their small size. The skulls are slightly under-represented in relation to the forelimbs and hind limbs, less in number of remains - essentially composed of teeth fragments - , than in minimum number of skeletal parts (M.N.S.P.). This higher representation of meat-rich parts, as well as the fragmentation 
TABLE 1. - Minimum Number of Skeletal Parts (M.N.S.P.) of camelids in the Offerings I deposit at Sipán.

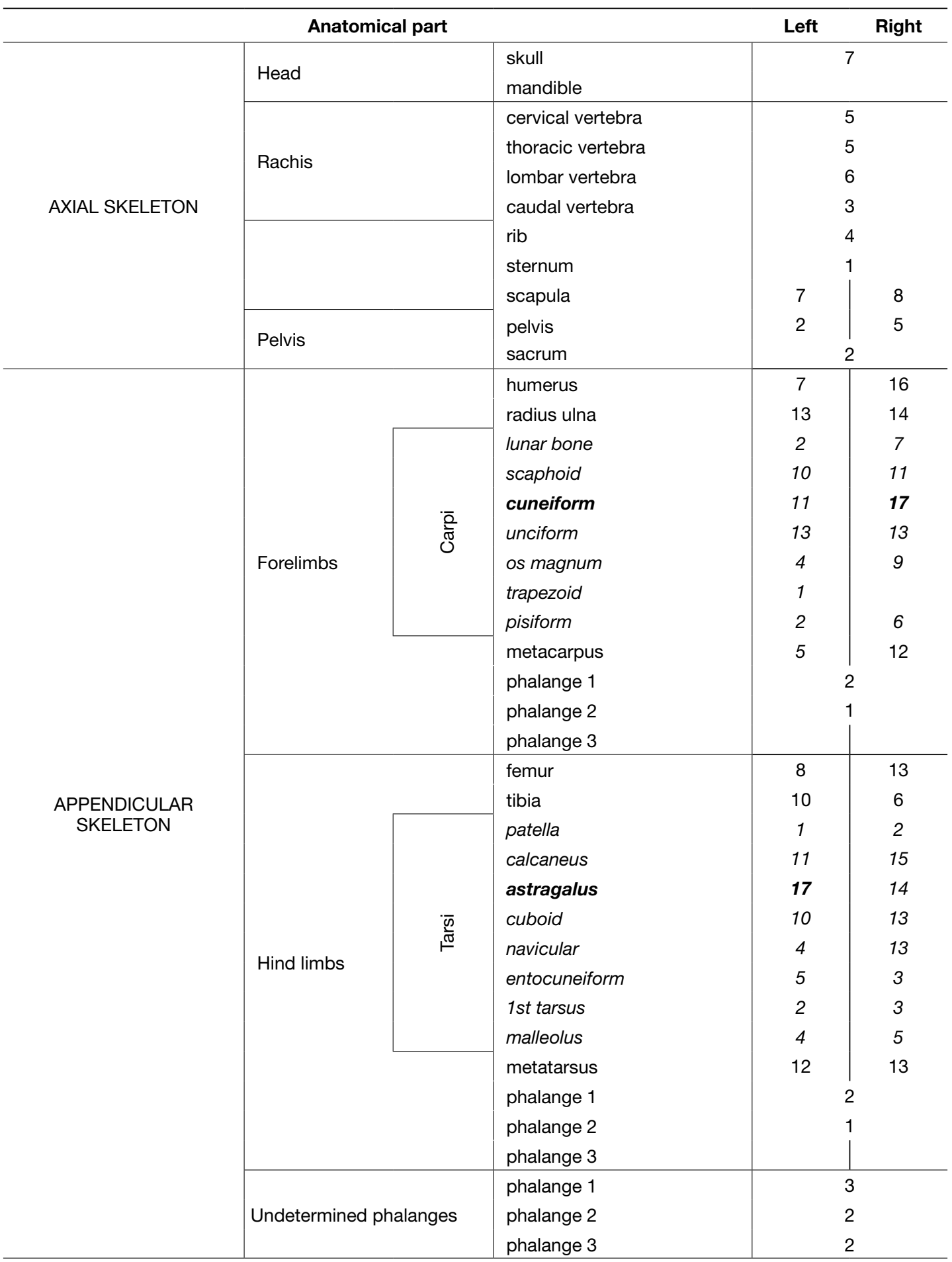


of these remains, seems to indicate that they represent culinary waste.

We have discovered only 34 traces of cutting, present mainly on the ribs, and to a lesser degree, on the cervical and thoracic vertebrae, the femurs, metatarsi, carpi and tarsi. Their location is evidence of the disarticulation and de-fleshing of the animals. There is an absence of traces of burning on these bone remains that have been identified as culinary waste. But as emphasized by S. Lepetz and W. Van Andringa (2008b: 23): "The passage through fire (grilled, skewered...) is the mode of preparation likely to leave the most traces [...] But there is no choice but to accept that these traces are rare and the proportion is never more than $2 \%$ of the bones analysed." It is also possible that the fire left no visible mark - surprising in consideration of the quantity of fragments - , so other modes of cooking meat and food must be considered, boiling in particular.

Because of the richness of the remains and the many precious objects placed within this ceremonial deposit, and its association with a tomb as prestigious as that of the "Lord of Sipán", this context cannot be confused with a domestic deposit and we presume that the consumption of these animals and the bone refuse in this structure could be the remnants of a funerary meal given in honour of the deceased. These arguments are certainly convincing and the characteristics of this deposit enable us to more easily set down the bases for future reflexion on the so-called banquet contexts of the Mochica, like the studies carried out for the Formative period (Ikehara \& Shibata 2008; VegaCenteno 2008), the compilations carried out by M. Dietler and B. Hayden (2001) and P. Kaulicke and T. Dillehay (2008) and work in Europe on the Greco-Roman and Gallo-Roman periods (Lepetz \& Van Andringa 2008a; Méniel 2001: 63-87).

\section{Extra-ordinary meals reserved for the elite?}

In his definition of feasts, P. Méniel (2001: 64) retains three criteria, of which one deals especially with the quantity of animals consumed during these meals, which exceeds domestic consumption. $\mathrm{He}$ describes several feasts dating to the Iron Age in which the quantities of meat consumed are considerable. For example, a shell midden dating to the $1^{\text {st }}$ Iron Age at Ouessant produced 21,000 remains corresponding to at least 460 sheep, 70 oxen, some thirty pigs, marine birds and fish (Méniel 2001: 65-67); at the Bellovaques, in the Oise valley, the remains of four horses discovered at Compiègne would have provided a weight in meat and fat evaluated at more than $500 \mathrm{~kg}$, and the discovery at Chevrières of the remains of six oxen and at least three pigs corresponds to more than $700 \mathrm{~kg}$ of meat (ibid.: 67-68).

In the Offerings I deposit at Sipán, we have identified the remains of at least 17 camelids, in particular the fleshy parts. These remains are highly fragmented and present traces of cutting, evidence of the disarticulation of the carcasses in order to prepare and cook them. All appears to confirm that these bones are the remnants of meals, and probably those of a funerary banquet that took place after the burial of the "Lord of Sipán". The overall estimate of the weight of the meat buried in this deposit is $191 \mathrm{~kg}$ (Goepfert 2009: 175-76), which shows that this funerary meal was reserved for a limited number of persons.

In the European contexts described by P. Méniel (2001: 64-68), the quantity of meat available, the calculation being based upon the faunal remains, clearly exceeds the estimates made for the bone remains from Offering I deposit at Sipán. In the end there is no choice but to accept that this estimate of $191 \mathrm{~kg}$ of meat is not such an exorbitant quantity as might appear at first, especially for a meal provided for such a grandiose funeral which may have taken place over several days in honour of such an important Mochica personage.

We presume however that camelid meat was not the only food consumed on this occasion and that other products, such as bone marrow, viscera, vegetables and fruit were also available. Thus, we believe that the quantity of meat estimated, $191 \mathrm{~kg}$, was sufficient for only a limited number of persons, a few dozen, perhaps a hundred. The iconography appears to confirm this hypothesis, as shown by the scenes of offering (Fig. 5) and of funerals described by C. Donnan and D. McClelland (1979: 7-8) and S. Bourget (2006: 186-223); the Mochica artists have depicted small groups of persons, especially the members of the Mochica elite. It may be imagined that this event reunited the family and 
friends of this high dignitary, as well as the religious and military authorities, delegations from elsewhere... Although socially this meal concerned only the members of the elite, its political range was wider and probably served to reaffirm the domination of the rulers over inferior social groups.

The nature of this funerary feast can also be investigated. Did it have a political character, reflecting the Mochica hierarchy, or was it a collective feast, in which social differences were erased for a time? Although we do not know the modes of transmission of power in the Mochica period, the end of the funeral may also have been a time of instability when plays of power and alliance could have taken place, especially during these meals.

It should be mentioned that this type of meal still occurs during funerals, on the coast (Velasquez Benites 2001) as well as on the southern sierra of Peru and the Bolivian altiplano where the family of the deceased gathers to watch over his soul and to share food (Carter 1968; Harris 1983; Robin Azevedo 2008).

In summary, camelid meat appears to have been the only meat consumed during these great festive events. Thus it had a particular importance as it was eaten by the living in their daily life as well as in the extraordinary conditions of funeral meals and food offerings for the deceased. On the other hand, deer meat is totally absent from these ritual contexts.

In the present state of our knowledge, it is still difficult to understand the elements which ruled, in the Mochica period, the relation between humans, llamas and deer. This is why, and to provide new information and avenues of reflection, we turn to later sources.

\section{ETHNOGRAPHIC EVIDENCE}

\section{PROPITIATORY CEREMONIES}

Although the chronological distance between the Mochica and the present is more than a thousand years, it may be quickly discerned that certain cultural features have been maintained, in spite of the continuous succession of various pre-Hispanic cultures and the Spanish conquest. Indeed, the introduction of new taxa (oxen, sheep, goats...) has considerably changed the economic life of the
Andean region, with for example the use of oxen for draught purposes. Even though the religious domain is not impervious to these modifications (use of sheep and chickens for sacrifices), the ancient traditions have persisted and the camelids, llamas and alpacas, as well as guinea pigs, remain the animals that are most used in the context of rituals taking place throughout the year (Girault 1975, 1988; Nachtigall 1975; Flores Ochoa 1977, 1988; Miller 1977; Lecoq 1987; Van den Berg 1990; Flores Ochoa et al. 1994; Flores Ochoa \& Kobayashi 2000; Lecoq \& Fidel 2000, 2003; Absi 2003).

These are usually propitiatory rituals carried out by shepherds to ask for protection and the increase of their herds, or by miners to request discovery of new veins or permanence in their activity. Here again, the use of the llama is twofold. Once sacrificed, its body is disarticulated and its meat prepared in order to be consumed by all the participants in the rites. It is above all a sacrificial victim to nourish the protective entities, the $A p u$ (mountain spirits), the Pachamama (Earth Mother) and the Tio (protective entity of mines). The blood of the animal could be spilled on the ground to nourish the Earth Mother, its heart and lungs were extracted to be burned as offerings (Fig. 12). Before this cremation, like the Inca priests five centuries earlier, the officiant - paqo or yatiri - examines these organs. He blows onto them in order to detect stains or roughness, which he interprets as good or bad omens, in order to know the fate of the crops or the herds (Lecoq \& Fidel 2000: 162167).

The heart and the lungs are then added to a larger complex offering, the mesa (Martinez 1987; Girault 1988; Fernandez Juarez 1995) which includes other elements (plant, animal, mineral, food, etc.), forming the whole gift. These offerings are then burned in a sacred place such as the top of a mountain or the interior of the mine. The organs of the llama constitute the preferred food of the spirits and their deposit on the fire represents the central act of the rite. The officiant then observes the manner in which the offerings are consumed by the flames to be sure that the particular divinity is well "fed", as the satisfaction of his appetite will ward off his anger. 


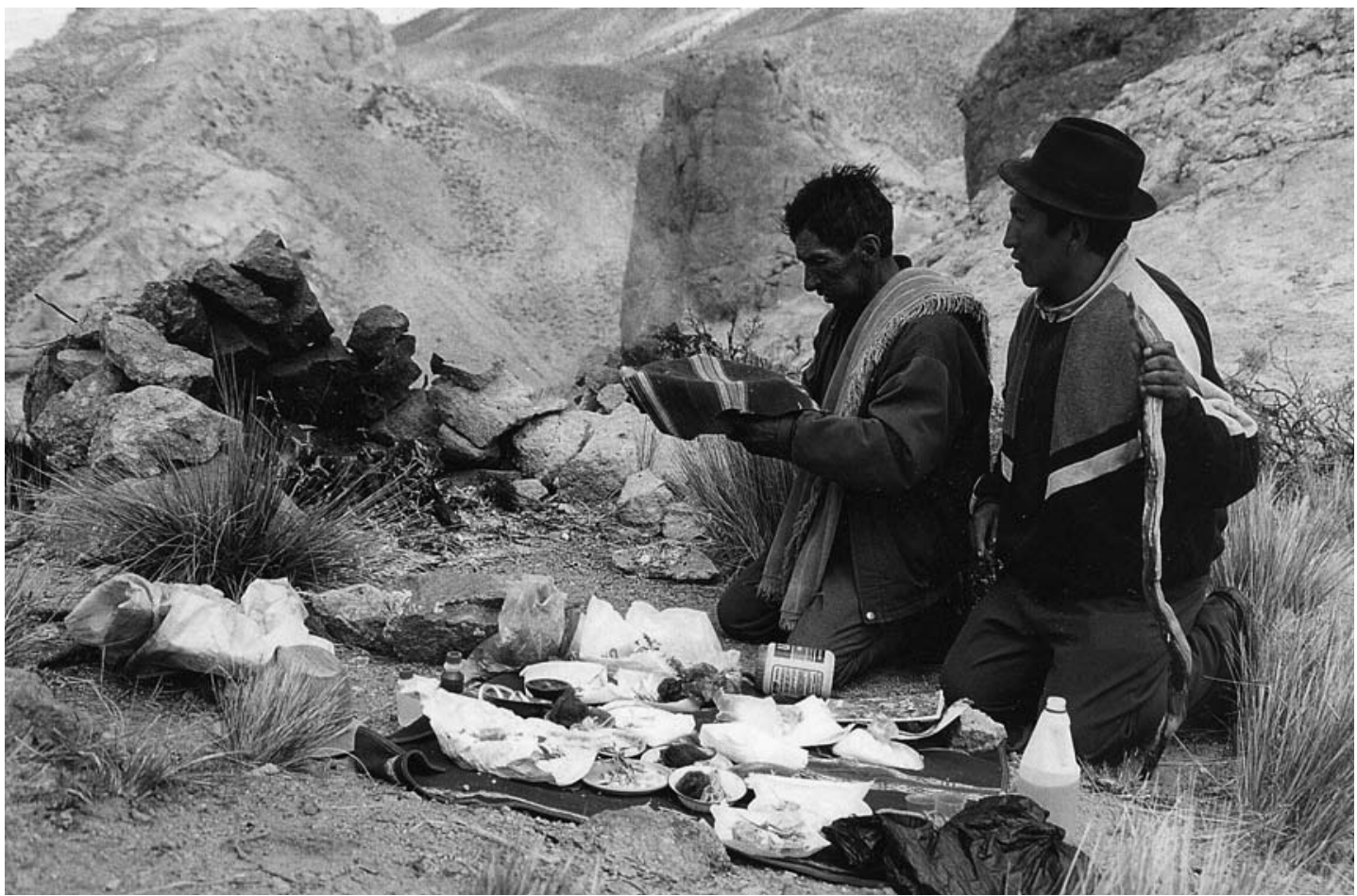

FIG. 12. - Incineration of a complex offering (mesa) containing the heart and the lungs of a llama sacrificed at Porco in Bolivia (Photo N. Goepfert).

Although other animals can be used, the llama is in practice the most prestigious animal sacrificed for these ends and the only one worthy enough to be offered by humans to the protective divinities. For different reasons (economic, environmental, etc.) the foetus of the llama (sullu en Quechua) can be offered as a substitute for the animal on the hoof. The camelids thus possess a particular status, as at no time would humans hunt a deer or any other wild animal to be a sacrifice and an offering. It is always a domestic animal, llama or alpaca, that is chosen for its purity, its colour and its vigour. Only these animals are appreciated by the divinities, and considering the exceptional character of the recipient of the offerings and of his culinary tastes, the sacrifice of camelids and the burning of their organs is most probably a new type of extra-ordinary consumption.

However, these rituals are not limited to the "great" protective entities. As in the Mochica tombs, the dead also receive a particular treatment involving the sacrifice of a llama — or a dog — to accompany him during his journey to the netherworld, but also a gift in kind of meat offerings, deposited in the tomb to feed him.

\section{CONTEMPORARY FUNERARY RITES}

Many ethnographic examples describe the role played by animals during funerary rites (Tschopik 1946, Robin Azevedo 2008). In her study on the attitude towards death and funerary rites in the Andes, V. Robin Azevedo (2004, 2008) describes the funerals of two communities in the region of Cuzco: Santo Tomás and Pampallacta, situated respectively in the provinces of Chumbivilcas and Calca. According to her, these rites are divided into three time periods: the funerary vigil, the burial and the expulsion of the soul from the deceased. Beginning with the funerary vigil, cooked and raw dishes are prepared and made availablfor the dead 
and the participants (Robin Azevedo 2008: 66-68, 76-77). After the burial, the inhabitants of each community must expel the soul of the deceased to prevent it, as previously mentioned, from disturbing the social order of the living and from provoking calamities. It appears then to be essential to maintain close spiritual relations with the deceased and to ensure that he has food. If the soul of the deceased is well fed, it will begin its journey under the best conditions and will liberate the community from possible troubles which its presence could cause. At Santo Tomás, the offerings are deposited on the back of a miniature llama, made with pieces of leather. V. Robin (2008: 71-72) states that "this animal serves to transport to the hereafter the provisions prepared by the relatives. The soul will carry them as food on its journey to its new life. The load, made up of twelve packages, is then attached onto the back of the miniature llama with braided cords. Part of the food is cooked so that it may be eaten on the journey, a snack (quqaw) for the travelling soul. The rest is raw, to be cooked at stops on the way". The offerings are then burned and cooking utensils are also added.

In this example, the llama serves as both food for the dead and as a beast of burden. This symbolic double function enables comprehension of the ambivalence of its role: psychopomp and object of consumption. It is necessary to point out that this is a non-pastoral community and that camelids are not present in the nearby environment, which confers an exceptional value on this example. We conclude that this ritual probably owes its origin to much earlier practices, dating to the pre-Hispanic period, when these species were herded in this province and occupied the surroundings. It is especially evidence for the power of the ritual function of these animals, which has persisted down the centuries, even in zones where camelids are now absent.

This is not a unique case. Eight days after the burial, the family goes to the cemetery to be sure that the soul of the dead has definitely left the community. It is the same at All Saints when the relatives of the dead bring food which they share with him
(Harris 1983: 141-145; Robin 2008: 123-140). The relatives attract the soul of the deceased with his favourite dishes; the soul appears in the form of an insect and once satisfied, goes back to the afterlife. The duration of these rituals varies according to the geographic zones. C. Bubba (1997: 392 ), in her article on the textiles of Coroma, indicates that "the jilaqata and sunaqa mallku are responsible for feeding the souls, changing every week the cooked food placed in a wayaqa (small sack) which is placed in the q'ipi. Above, two small glasses of pure alcohol and coca leaves are placed"5. She states, a few lines later, that this alcohol is considered to be the maternal milk that comes from the breast of the ancestors, stressing the "vital" link that ties the living to their ancestors. The souls of the dead continue to be nourished for years in order to receive in return their protection and generosity. The food offerings are given by the living to the dead, but also to the divinities who help them to live in the afterlife. In the Andes, this principle of reciprocity is called ayni (Bouysse-Cassagne $\&$ Harris 1987: 32), the gift of food being a ritual application of this concept. Cemeteries are not considered to be closed spaces and these rites of symbolic communion and union between the living and the dead enable consolidation of the old order. These practices probably go back to the pre-Hispanic period, the first written evidence dating to the $16^{\text {th }}$ and $17^{\text {th }}$ centuries when the many legal proceedings concerning idolatry are evidence of their continuation (Duviols 1971, 2003). Spanish priests described with horror Indians (recently colonised and Christianised) sacrificing llamas and guinea pigs, offering coca, maize, drinking chicha and dancing with their dead, not wishing to break with their ancient beliefs.

The relation between the living and the dead is fundamental to understanding the social balance of the Andean communities. Only an appeased dead individual will be benevolent towards the population, which is why particular attention is attached to food for the dead and their souls, especially to the sacrifice of camelids, which occurs

5. The translation from Spanish to French is ours: "Los jilaqata et sunaqa mallku están encargados de alimentar a las almas, cambiando cada semana la comida cocida que se coloca en una wayaqa (talega pequeña) que se coloca dentro del qiipi. Encima de éste, se colocan dos copitas de alcohol puro y hojas de coca”. 
throughout the year. However, this role of mediator between the terrestrial and the divine is also played by deer, although they are never captured or sacrificed.

\section{THE DEER AND THE REALM OF DIVINITIES}

Citing a myth reproduced in the manuscript of Huarochiri' ${ }^{6}$, A-M Hocquenghem (1983: 78) stresses the role of the deer in Mochica iconography as an intermediary between humans and their ancestors, because it "lives at the limit between cultivated lands and wild lands, moves from the valleys to the mountains, appears during the dry season and disappears during the wet season, can pass from the world of the living to that of the dead, of which it is often the representative, the temporary refuge or the associate". Thus, "this role of mediator between two opposed and complementary parts of a whole explains why, of the all the animals hunted, it is the deer that is offered by the living to their ancestors." As A-M. Hocquenghem stresses and J. Flores Ochoa has already mentioned (1974-76: 256), the deer belongs to the realm of the ancestors and the protective entities, and thus to the wild, a world forbidden to humans.

These beliefs are not unique to the southern sierra of Peru. Parallels can be drawn with other regions of the Andes (Renard-Casevitz 1979), like the White Cordillera (Walter 2003) which includes the highest point in Peru, the Huascarán (6768 m). In this region, the deer is called tarugo (a term close to taruka) and is part of the group of animals of the "grandfathers", the abuelitos, figures symbolising the tutelary spirits of the mountain, entities which correspond to the $A p u$ in the southern cordillera. D. Walter (2003: 91) indicates that "the tarugo belongs to the abuelito, and is moreover his most precious animal' and that the hunting of deer is the most difficult and "is placed under his control and authorisation." This observation emphasizes the very particular closeness between the deer, the mountain and the world of the spirits. It is not then a common animal and even hunting deer is subject to many rituals and limitations (ibid.: 91-98). In a superb metaphor, the avalanches that hurtle down the glaciers become the "breath of the deer", the rabu tarush (Walter 2003: 105-108), the figure of the deer literally personifying the mountain, all of the wild domain and the divinities which populate it.

\section{CONCLUSIONS}

All of these data are evidence of a real dichotomy between the llama and the deer, but also between the domestic and the wild, the world of the living and that of the ancestors, the inherited oppositions of dualism, a concept providing a subtle ritual balance.

The omnipresence of camelids in the funerary and ceremonial contexts of the pre-Hispanic period would explain the relative absence of deer remains in most of these. With rare exceptions, offerings of deer as such are non-existent. It would seem that these animals were never considered in the Andes to be an unusual food, worthy of being offered to the dead or to divinities. In spite of its status as game, its meat was never presented to the protective entities, because as the ethnographic evidence indicates, the deer already belongs to the realm of the wild.

Deer are part of the herds of the $A p u$ and cannot be taken by the common run of people. The hunting of deer, of which there are many representations in Mochica iconography, takes on a particular character with the presence of elite personages. It could thus be considered that the hunting of deer was maintained artificially, perhaps for ritual reasons, which remain unknown. To honour their divinities and their ancestors, humans had to offer them worldly and domestic food, especially camelids. This work also shows that the function of camelid meat as food persisted through the centuries and that only llamas and alpacas, symbols of the reciprocity between Andean communities and the divinities, were considered to be worthy sacrificial victims.

The dichotomy of their status (wild and domestic) would have justified the substitution — in the

6. This is a work that compiles the myths and religious beliefs of the inhabitants of the region of Huarochiri in Peru. This information was collected by the Spanish priest Francisco de Avila in the $17^{\text {th }}$ century (Taylor 1980). 
tombs and in the provision of food for the dead - of the deer by the llama, the property of humans. These two taxa are the representatives of two opposing but complementary worlds, whose reciprocal relationship is ruled by dualism. Symbolic and functional doubles whose principal role is the transport of loads for humans and for the $A p u$, they are opposites in the modes that we find elsewhere: domestic/wild, world of the living/world of the dead, herding/hunting, day/night.

The llama and the deer crystallise one part of the play of oppositions and symbolic complementarities in the Andean sacrificial rituals. The revelation of this dualistic relationship clarifies, it seems to us, the reasons for the presence or absence of these taxa in funerary and ceremonial archaeological contexts, however ancient. The Mochica, as appears to be the case in all of the central Andes, favoured the use of domestic camelids for their rituals, because these animals were a legacy from the divinities to humans for their prosperity. These protective entities are themselves the owners of groups of wild animals, such as deer and foxes, which are not directly implicated — certainly not materially — in the ceremonial realm and the funerary rites of Andean populations.

\section{Acknowledgments}

I thank the directors (C. Chauchat, W. Alva, L. J. Castillo, R. Franco, C. Galvez, S. Valquez, S. Uceda and R. Morales) of the Mochica archeological sites which allow me to study the faunistic material resulting from the burials and offerings deposits excavations, base of this work on Andean rituals. I also thank the Canteria communities in Peru and Porco in Bolivia which authorized me to take part in their ceremonies, and S. Fidel who accompanied me at these rituals. I particularly thank C. Lefèvre, P. Lecoq and C. Chauchat for their many comments on methodology, environment and religious beliefs. I also thank M. Ballinger and the various people who worked on the finalization of this article. By its multi-field approach and the use of various sources (archaeological, iconographic, ethnographic), this article is a modest contribution to the important antropozoological work of F. Poplin to whom I wish to dedicate this article.

\section{REFERENCES}

Aвsı P. 2003. - Les ministres du diable. Le travail et ses représentations dans les mines de Potosi, Bolivie. L'Harmattan, Paris.

Alva W. 2004. - Sipán. Descubrimiento e investigación. Éd. auteur, Lima.

Alva W. \& Donnan C.B. 1993. - Royal Tombs of Sipán. Fowler Museum of Cultural History; University of California, Los Angeles.

Arriaga P. J. DE 1920 [1621]. - La Extirpación de la idolatria en el Perú. Tomo I, Colección de libros y documentos en la historia del Perú. Microfilm, 137 vues. Imprenta y Libreria San Martin y Ca, Lima.

Arsenault D. 1992. - Pratiques alimentaires rituelles dans la société mochica : le contexte du festin. Recherches amérindiennes au Québec 22(1): 45-64.

Benson E.P. 1972. - The Mochica. A Culture of Peru. Praeger Publishers, New York; Washington.

Benson E.P. 1975. - Death and Afterlife in PreColumbian America. A conference at Dumbarton Oaks (October 27th, 1973), Dumbarton Oaks Research Library and Collections, Washington.

Berrin K. 1997. - The Spirit of Ancient Peru. Treasures from the Museo Arqueológico Rafael Larco Herrera. Thames and Hudson, New York.

Bourget S. 2006. - Sex, death, and sacrifice in Moche religion and visual culture. University of Texas Press, Austin.

Bouysse-Cassagne T. 1988. - Lluvias y Cenizas. Dos Pachacuti en la Historia. Hisbol, La Paz [avec la collaboration de P. Bouysse].

Bouysse-Cassagne T. \& Harris O. 1987. — Pacha : en torno al pensamiento aymara, in BouysseCassagne T., Harris O., Platt T. \& Cereceda V., Tres reflexiones sobre el pensamiento andino. Hisbol, La Paz : 11-59.

Browman D. 1974. - Pastoral Nomadism in the Andes. Current Anthropology 15 (2) : 188-196.

Bubba C. 1997. — Los rituales a los vestidos de Maria Titiqhawa, Juana Palla y otros fundadores de los ayllu de Coroma, in Bouysse-Cassagne T. (éd.), Saberes y Memorias en los Andes. In Memoriam Thierry Saignes. Travaux de l'Institut Français d'Études Andines (IFEA) 97. Credal-IFEA, Lima : 377-400.

Carter W.E. 1968. - Secular Reinforcement in Aymara Death Ritual. American Anthropologist 70 (2): 238-263.

Castillo Butters L. J. 2000. — Los rituales mochica de la muerte, in Makowsкi K., Los dioses del Antiguo Perú. Banco del Credito, Lima : 103-135.

Chauchat C. 2000. - Grande cité de Moche. Découvertes dans la mystérieuse. Archeologia 368 : 32-41.

Chauchat C. \& Gutiérrez B. 2007. - Excavaciones en la Plataforma Uhle, in UCEDA S. \& 
Morales R., Informe técnico 2006. Proyecto Arqueológico Huaca de la Luna. Facultad de Ciencias Sociales; Universidad Nacional de la Libertad; Backus; Fondación Wilson, Trujillo: 47-87.

Chauchat C. \& Gutiérrez B. 2008. - Excavaciones en la Plataforma Uhle. Informe técnico 2007. Proyecto Arqueológico Huaca de la Luna. Facultad de Ciencias Sociales; Universidad Nacional de la Libertad ; Backus; Fondación Wilson, Trujillo: 33-78.

Chauchat C., Gutiérrez B., Deverly D. \& Goepfert N. 2008. — Recherches sur l'élite de la société mochica. La plateforme Uhle à Moche, sur la côte nord du Pérou. Les Nouvelles de l'Archéologie 111-112 : 116-122.

Dietler M. \& Hayden B. 2001. - Feasts: Archaeological and Ethnographic Perspectives on Food, Politics, and Power. Smithsonian Institution Press, Washington D.C.

Donnan C.B. 1978. - Moche Art of Peru. PreColumbian Symbolic Communication. Museum of Cultural History; University of California, Los Angeles.

Donnan C.B. 1982a. - La caza del venado en el arte mochica. Revista del Museo Nacional 16 : 235-251.

Donnan C.B. 1982b. — Dance in Moche Art. Nawpa Pacha 20: 97-120.

Donnan C.B. 1995. - Moche Funerary Practices, in Dillehay T. (éd.), Tombs for the Living: Andean Mortuary Practices. A Symposium at Dumbarton Oaks, $12^{\text {th }}$ and 13 th October 1991. Dumbarton Oaks Research Library and Collection, Washington D.C.: 111-159.

Donnan C.B. 2008. - Moche Tombs at Dos Cabezas. Monograph 59. Cotsen Institute of Archaeology at UCLA, Los Angeles.

Donnan C.B. \& McClelland D. 1979. - The Burial Theme in Moche iconography. Studies in PreColumbian Art and Archaeology 21. Dumbarton Oaks, Washington D.C.

Duviols P. 1971. — La lutte contre les religions autochtones du Pérou colonial : "L'extirpation de l'idolâtrie" entre 1532 et 1660. Travaux de l'Institut Français d'Études Andines (IFEA) 13. IFEA-Ophrys, Lima.

Duviols P. 2003. - Procesos y Visitas de Idolatrias. Cajatambo, siglo XVII. Travaux de l'Institut Français d'Etudes Andines (IFEA) 94. IFEA-PUCP, Lima.

Fernandez Juarez G. 1995. - El banquete aymara. Mesas y yatiris. Hisbol, La Paz.

Flores OchoA J.A. 1974-76. — Enqa, Enqaychu, Illa y Khuya Rumi: Aspectos mágicos-religiosos entre pastores. Journal de la Société des Américanistes 83 : 245-262.

Flores Ochoa J.A. 1977. — Pastores de puna. Uywamichiq punarunakuna. IEP, Lima.

Flores OchoA J.A. 1988. — LLamichos y paqocheros: Pastores de llamas y alpacas. Centro de Estudios Andinos, Cusco.
Flores Ochoa J.A. \& Kobayashi Y. 2000. - Pastoreo Altoandino. Realidad, sacralidad y posibilidades. Plural-Musef, La Paz.

Flores Ochoa J.A., MacQuarrie K. \& Portus J. 1994. - Oro de los Andes. Las Llamas, Alpacas, Vicuñas y Guanacos de Sudamérica. Jordi Blassi, Barcelone.

Girault L. 1975. — Les fotus animaux dans le rituel des indiens andins (Bolivie), in Pujol R. (éd.), L'homme et l'animal : Premier colloque d'ethnozoologie, Paris (28-30 nov. 1973). Institut international d'ethnosciences, Paris : 217-226.

Girault L. 1988. - Rituales en la región andinas de Bolivia y Perú. Ceres; Musef; Quipus, La Paz.

Goepfert N. 2002. - Le sacrifice des camélidés au Pérou du Précéramique aux Incas. Mémoire de DEA. Université Paris 1 Panthéon-Sorbonne, Paris.

Goepfert N. 2008. — Ofrendas y sacrificio de animales en la cultura mochica: el ejemplo de la Plataforma Uhle, Complejo Arqueológico Huacas del Sol y de la Luna, in Castillo L.J., Bernier H., Lockard G. \& Rucabado J., Arqueología Mochica. Nuevos Enfoques. Actas del Primer Congreso Internacional de Jóvenes Investigadores de la Cultura Mochica, Lima, 4-5 de agosto de 2004. Institut Français d'Études Andines ; Fondo Editorial de la Pontificia Universidad Católico del Perú, Lima : 231-244.

Goepfert N. 2009. — Rites funéraires, offrandes et sacrifice animal dans l'idéologie religieuse de la culture Mochica (100-800 apr. J.-C.), côte nord du Pérou. Thèse $3^{\mathrm{e}}$ cycle. Université Paris 1 PanthéonSorbonne, Paris.

Gumerman G. 1994. - Corn for the dead: the significance of Zea mays in Moche burial offerings, in Johannessen S. \& Hastorf C.A. (eds), Corn and Culture in the Prehistoric New World. Westview press, Boulder.

Gumerman G. 1997. - Botanical offerings in Moche burials at Pacatnamu, in Donnan C.B. \& Cock G., The Pacatnamu Papers. Vol. 2. Fowler Museum of Cultural History; University of California, Los Angeles : 243-249.

Harris O. 1983. - Los muertos y el diablo entre los laymi de Bolivia. Chungara 11 : 135-152.

Hocquenghem A.-M. 1983. - Les cerfs et les morts dans l'iconographie mochica. Journal de la Société des Américanistes 69 : 71-84.

Hocquenghem A.-M. 1987. - Iconografía Mochica. Fondo Editorial de la Pontificia Universidad Católica del Perú, Lima.

Imehara H. \& Shibata K. 2008. - Festines e integración social en el Periodo Formativo: nuevas evidencias de Cerro Blanco, valle bajo de Nepeña, in Kaulicke P. \& Dillehay T. D., Boletin de Arqueología PUCP $n^{\circ}$ 9-2005. Encuentros: Identitad, poder y manejo de espacios públicos. Pontificia Universidad Catolica del Perú (PUCP), Lima : 123-159. 
Izumi S. \& Sono T. 1963. - Andes 2. Excavations at Kotosh, Peru, 1960. University of Tokyo; Kadokawa Publishing, Tokyo.

Kaulicke P. 2000 - Memoria y Muerte en el Perú Antiguo, Fondo Editorial-Pontificia Universidad Católica del Perú, Lima.

Kaulicke P. \& Dillehay T. D. 2008. - Boletin de Arqueologia PUCP $n^{\circ}$ 9-2005. Encuentros: Identitad, poder y manejo de espacios públicos. Pontificia Universidad Catolica del Perú (PUCP), Lima.

Kutscher G. 1983. - Nordperuanische Gefä凶malerein des Moche-Stils, Materialen zur Allgemeinen und Vergleichenden Archäologie. Band 18, Verlag C.H. Beck, Munich.

Larco Hoyle R.1939. - Los Mochicas. Tomo 2. Casa editora La Crónica y Variedades S.A., Lima.

LAVAlléE D. 1990. - La domestication animale en Amérique du Sud : le point des connaissances. Bulletin de l'Institut Français d'Études Andines (IFEA) 19 (1) : 25-44.

Lavallée D., Julien M., Wheeler J.C. \& Karlin C. 1985. - Telarmachay. Chasseurs et pasteurs préhistoriques des Andes. Éditions Recherche sur les Civilisations, Paris.

Lecoq P. 1987. - Caravanes de lamas, sel et échanges dans une communauté de Potosí, en Bolivie. Bulletin de l'Institut Français d'Études Andines (IFEA) 16 (3-4) : 1-38.

Lecoq P. \& Fidel S. 2000. - Algunos aspectos de la vida de los ritos ganaderos en Ventilla, una comunidad pastoral del sur de Potosí, Bolivia, in Flores Ochoa J.A. \& Kobayashi Y., Pastoreo Altoandino. Realidad, sacralidad y posibilidades. Plural-Musef, La Paz : 149-187.

Lecoq P. \& Fidel S. 2003. - Prendas simbólicas de camélidos y ritos agro-pastorales en el sur de Bolivia. Textos Antropológicos 14 (1) : 7-54.

Lepetz S. \& VAn Andringa W. 2008a. - Archéologie du sacrifice animal en Gaule romaine. Rituels et pratiques alimentaires. Édition Monique Mergoil, Montagnac.

Lepetz S. \& VAn Andringa W. 2008b. — Les os et le sacrifice : problèmes de méthode, in LePETz $S$. \& VAn Andringa W., Archéologie du sacrifice animal en Gaule romaine. Rituels et pratiques alimentaires. Édition Monique Mergoil, Montagnac : 11-26.

Martinez G. 1987. - Una mesa rituel en Sucre. Aproximaciones semióticas al ritual andino. Hisbol, La Paz.

Mengoni Goñalons G. L. 2001. — Variabilidad de la anatomía de económica en la llama, in Mengoni G.L., Olivera D.E. \& YacobacCio H.D., El Uso de los camélidos a través el tiempo. Ediciones del Tridente; GZC; ICAZ, Buenos Aires : 145-153.

Méniel P. 1992. - Les sacrifices d'animaux chez les Gaulois. Éditions Errance, Paris.

Méniel P. 2001. — Les Gaulois et les Animaux. Elevage, repas et sacrifice. Éditions Errance, Paris.
Millaire J.-F. 2002. - Moche burial patterns: An investigation into Prehispanic social structure. B.A.R. (British Archaeological Records) International Series 1066. Archaeopress, Oxford.

Miller G. R. 1977. — Sacrificio y beneficio de camélidos en el sur del Perú, in Flores OchoA J.A. (éd.), Pastores de puna. Uywamichiq punarunakuna. IEP, Lima : 193-210.

Millones L. \& Kapsoli W 2001. - La Memoria de los Ancestros. Universidad Ricardo Palma; Editorial Universitaria, Lima.

Nachtigall H. 1975. - Ofrendas de llamas en la vida ceremonial de los pastores. Allpanchis Phuturinqa $8: 133-140$.

Olivera D.E. 2001. - Perfil etario y rendimiento económico de Lama glama, in Mengoni G.L., Olivera D.E. \& Yacobaccio H.D., El Uso de los camélidos a través el tiempo. Ediciones del Tridente; GZC; ICAZ, Buenos Aires: 179-202.

Pozorski S.G. 1976. - Prehistoric subsistence patterns and site economics in the Moche valley, Peru. PhD. Université du Texas, Austin.

Pozzi-Escot D. \& Cardoza C.R. 1986. - El consumo de camélidos entre el Formativo y Wari en Ayacucho. INDEA; Universidad Nacional San Cristóbal de Huamanga, Ayacucho.

Renard-Casevitz F.-M. 1979. - Su-açu. Essai sur les cervidés de l'Amazonie et sur leur signification dans les cultures indiennes actuelles. Travaux de l'Institut Français d'Études Andines (IFEA) 20. IFEA ; CNRS, Paris ; Lima.

Robin Azevedo V. 2004. — La Divine Comédie dans les Andes ou les tribulations du mort dans son voyage vers l'au-delà. Journal de la Société des Américanistes 90 (1) : 143-181.

Robin Azevedo V. 2008. - Miroirs de l'autre vie. Pratiques rituelles et discours sur les morts dans les Andes de Cuzco (Pérou), Société d'Ethnologie, Nanterre.

Shimada M. \& Shimada I. 1985. - Prehistoric llama breeding and herding in the north coast. American Antiquity 50 (1): 3-26.

Stanley H. F., Kadwell M. \& Wheeler J. C. 1994. - Molecular evolution of the family Camelidae: a mitochondrial DNA study. Proceeding of the Royal Society of London 256: 1-6.

TAYlOR G. 1980. - Rites et tradition de Huarochiri : manuscrit quechua $d u$ début $d u 17^{e}$ siècle. L'Harmattan, Paris.

TschOpIK Jr H. 1946. - The Aymara, in STEWARD J., Handbook of South American Indians. Vol. 2. The Andean Civilizations. Bulletin 143. Smithsonian Institution, Bureau of American Ethnology, Washington D.C.: 501-574.

VAN Den Berg H. 1990. - La Tierra no da asi nomás. Los ritos agrícolas en la religión de los AymarasCristianos. Hisbol-Ucb-Iset, La Paz.

VALdez L.M. 1988. — Los camélidos en la subsistencia Nasca, el caso de Kawachi. Boletin de Lima 57 : 31-35. 
Vasquez V.F., Rosales T.E., Morales A. \& Rosello E. 2003. - Zooarqueología de la Zona Urbana Moche, Complejo Huacas del Sol y de la Luna, valle de Moche, in Uceda S. \& Mujica E. (eds), Moche. Hacia el final del milenio. Actas del Segundo Coloquio sobre la Cultura Moche, Trujillo, 1 al 7 de agosto de 1999. Vol. 2. Pontificia Universidad Católica del Perú-Universidad Nacional de la Libertad, Trujillo : 33-63.

Vega-Centeno R. 2008. - Consumo y ritual en la construcción de espacios públicos para el Periodo Arcaico Tardio: el caso de Carro Lampay, in KaUlicke P. \& Dillehay T.D., Encuentros: Identitad, poder y manejo de espacios públicos. Boletin de
Arqueología PUCP 9-2005. Pontificia Universidad Catolica del Perú (PUCP), Lima : 91-121.

Velasquez Benites O. 2001. - Los muertos viven en el norte del Perú, in Millones L. \& Kapsoli W., La Memoria de los Ancestros. Universidad Ricardo Palma-Editorial Universitaria, Lima : 153-189.

Walter D. 2003. - La domestication de la nature dans les Andes péruviennes. L'alpiniste, le paysan et le Parc National du Huascarán. L'Harmattan, Paris.

Wheeler J.C. 1985. — De la caza a la domesticación, in Lavallée D., Julien M., Wheeler J.C. \& Kardin C. (éds), Telarmarchay. Chasseurs et Pasteurs préhistoriques des Andes. Éditions Recherche sur les Civilisations, Paris : 49-68.

Soumis le 1er juin 2009; accepté le 26 mars 2010. 